\title{
Unilateral Hydrocephalus: Atypical Presentation of Intracranial Tuberculoma
}

\section{Tek Tarafl Hidrosefali: Intrakranyal Tüberkülomun Atipik Bir Sunumu}

Deepak Kumar SINGH, Manu RASTOGI, Anurag SHARMA, Mazhar HUSAIN

Sahara Hospital, Department of Neurosurgery, Lucknow, India

Correspondence address: Deepak Kumar SİNGH / E-mail: gkp.deepak@gmail.com

\begin{abstract}
A 43-year-old male presented with 3-month history of low-grade fever and headache. Radiological investigations revealed unilateral hydrocephalus. Unilateral obstruction of the foramen of Monro due to chronic tubercular ependymal inflammation was suspected and endoscopic septostomy was planned. Though ventriculo-peritoneal shunt is a simple method to treat hydrocephalus, complications related to this procedure are numerous. Neuroendoscopy is a safe method to treat hydrocephalus in selected cases, and also provides access to biopsy the lesion in question. An isolated tuberculoma obstructing the foramen of Monro was seen during endoscopy. Presentation and management of this unusual tuberculoma is reported along with a review of the pertinent literature.
\end{abstract}

KEYWORDS: Unilateral hydrocephalus, Tuberculoma, Foramen of monro, Septostomy, Unusual presentation

öz

43 yaşında bir erkek hasta 3 aylık subfebril ateş ve başağrısı ile başvurdu. Radyolojik incelemeler tek taraflı bir hidrosefali gösterdi. Kronik tüberküler epandimal inflamasyona bağlı Foramen Monro tıkanıklığından şüphelenildi ve endoskopik septostomi planlandı. Ventiküloperitoneal şant hidrosefali tedavisinde basit bir metod olmasına rağmen bu işlemle ilgili çok fazla komplikasyon vardır. Nöroendoskopi seçilmiş vakalarda hidrosefali tedavisinde güvenli bir yöntemdir ve ayrıca söz konusu lezyondan biyopsi alma imkanı da sağlar. Endoskopi sırasında foramen Monro'yu tıkayan izole bir tüberkülom görüldü. Bu alışılmadık tüberkülomun sunumu ve tedavisi mevcut literatürün eşliğinde tartışıldı.

ANAHTAR SÖZCÜKLER: Tek tarafıı hidrosefali, Tüberkülom, Foramen monro, Septostomi, Alışılmadık sunum

\section{INTRODUCTION}

An intracranial tuberculoma results from hematogenous seeding of tubercle bacilli to the leptomeninges or brain parenchyma. Despite the wide accessibility of anti- tubercular drugs, is still the most common infective granuloma of the central nervous system. The usual clinical presentations are those of a progressive space-occupying lesion showing signs of increased intracranial pressure with or without localized neurological signs, and progressive neurological disability without raised intracranial pressure (3). We describe the presentation and management of a single tuberculoma obstructing the foramen of Monro and causing unilateral hydrocephalus.

\section{CASE REPORT}

A 43-year-old right-handed male presented with history of low-grade fever and headache of 6-month duration. He also had a 7-day history of progressively changing behavior. There was no history of visual deterioration or neck stiffness. Examination revealed cognitive dysfunction in terms of aggressive behaviour and memory disturbances. Cranial CT and $M R I$ (Figure $1 A, B, C$ ) revealed a markedly dilated right lateral ventricle with a midline shift to the left. Membranous occlusion of the right foramen of Monro (arrow) was seen. Septum pellucidum was intact and the third ventricle was normal in appearance. There were no masses or associated anomalies seen. E.S.R. was $40 \mathrm{~mm} / 1$ st hour. Other hematological and radiological investigations were grossly normal. Chronic ependymal inflammation was considered for this membranous occlusion of right foramen of Monro. An emergency neuro-endoscopic septostomy with fenestration of the occluded foramen was planned. A peelaway sheath (14.0 Fr.; Universal Gaab Sys.) was passed into the anterior horn of right lateral ventricle through a standard coronal burr hole. A rigid $4 \mathrm{~mm}$ diameter endoscope (Karl storz inc.) was then inserted into the right lateral ventricle through the peelaway sheath. Exploration of lateral ventricle revealed an isolated small rounded mass obstructing the right foramen of Monro (Figure 2A). The mass densely adhered to the fornix and choroid plexus. A biopsy taken from the mass (Figure $2 B$ ). Fenestration of septum pellucidum between the anterior and posterior septal veins was performed with low-current monopolar coagulation and a Fogarty balloon catheter to form a stoma of $10 \mathrm{~mm}$. (Figure 2C) The results of CSF analyses 


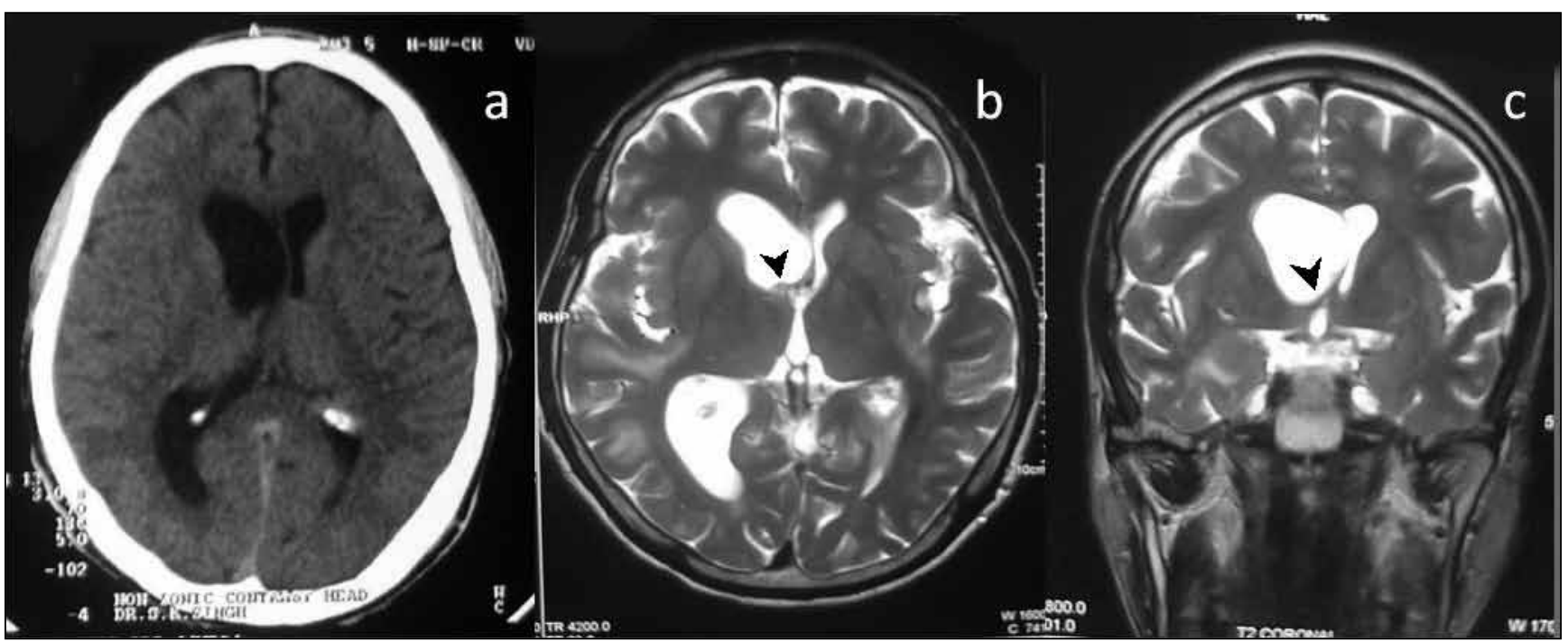

Figure 1: A) CT head showing asymmetrical hydrocephalus. B-C) MRIT2W axial and coronal images showing asymmetrical enlargement of the right ventricle. Apparent membranous occlusion of the right Foramen of Monro is also seen (arrow head).

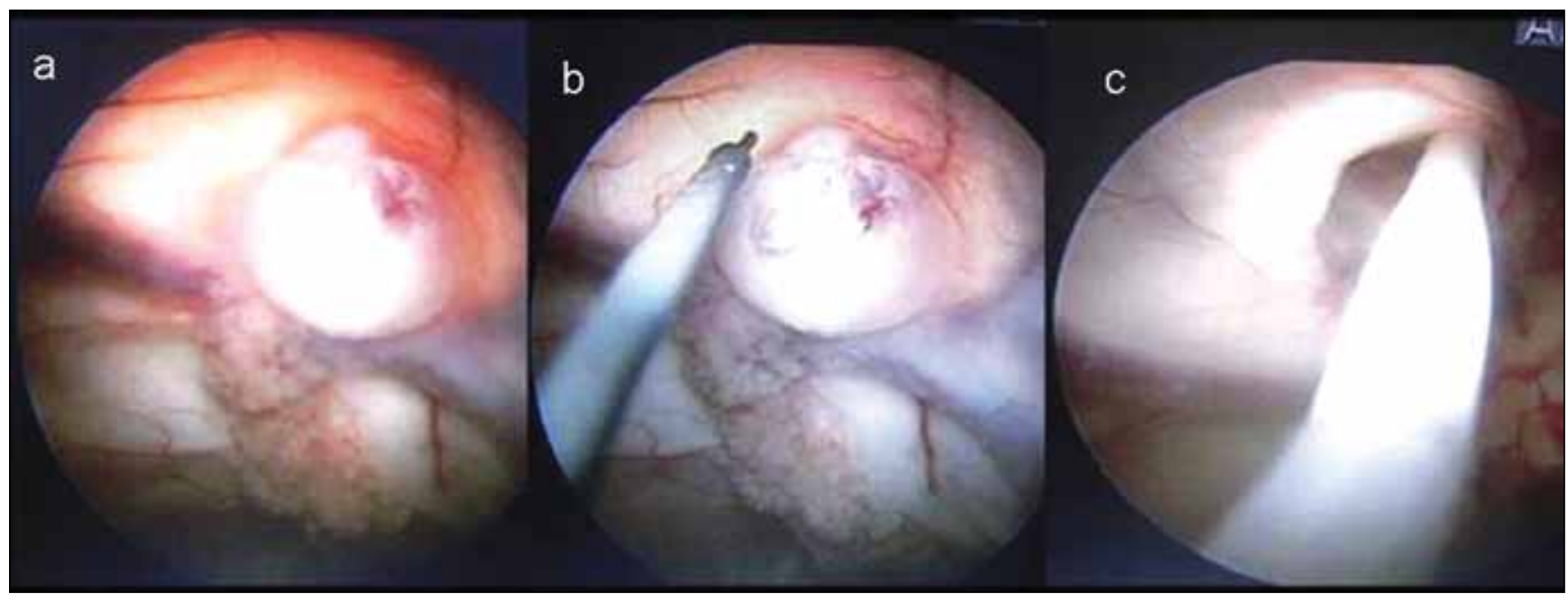

Figure 2: Peroperative endoscopic images. A) A single tuberculoma obstructing the foramen (Note the choroid plexus and thalamostriate vein signifying the Foramen of Monro). B) Biopsy being taken from the mass. C) Septostomy performed between the anterior and posterior septal veins.

and histopathological examination of excised tissue mass revealed a small necrotizing granulomas with surrounding lymphocyte accumulation, epithelial cells and Langhans giant cells. The appearance was consistent with that of a tuberculoma. (Figure 3) The cognitive functions of the patient improved significantly after surgery. He was discharged on the 7th post-operative day on oral anti-tubercular drugs and was asymptomatic at 2-month follow-up.

\section{DISCUSSION}

Tuberculomas of the brain account for 20 to 30 percent of intracranial tumors in developing countries (13). Tuberculomas develop due to local expansion of a "Rich focus" within the brain parenchyma. They may also originate in the meninges, and may be found in the superficial cortex.

Tuberculomas may be multiple or miliary (6), although most patients have a single or confluent large granuloma with a necrotic centre.

$\mathrm{MRI}$ is the diagnostic modality of choice. Tuberculomas are isointense with grey matter on Tl-weighted MR images. The lesions show central hyperintensity on T2-weighted images. A hypointense ring may be present within the wall of the tuberculoma on T2-weighted images. Most tuberculomas are further outlined by a collar of high signal, resulting from oedema, on T2-weighted images. Tuberculomas,typically 


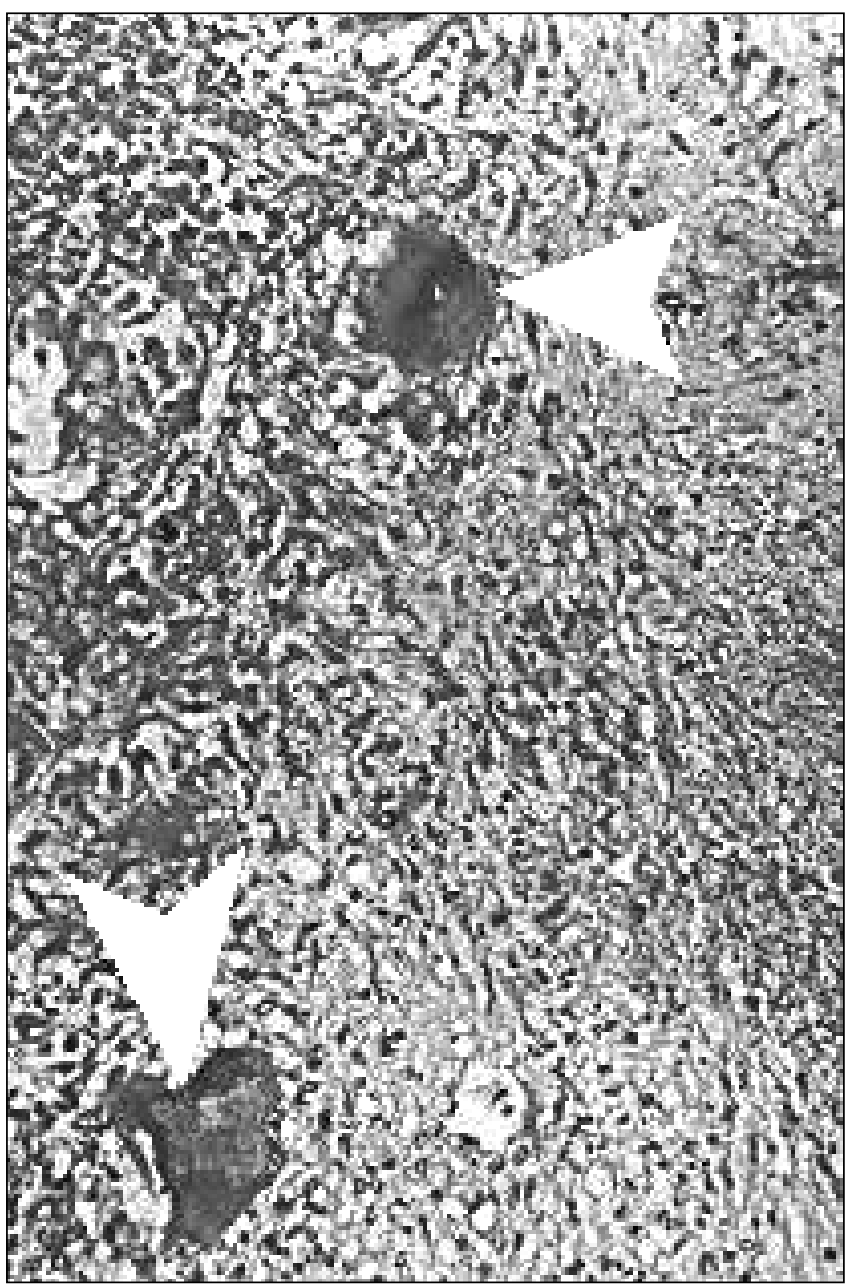

Figure 3: Small necrotizing granulomas (arrowheads) with surrounding lymphocyte accumulation, epithelial cells and Langhans giant cells. (HE-100X).

"enhance" in a solid or ring pattern after the intravenous administration of gadopentetate dimeglumine $(4,7)$. The CT/ MRI diagnosis of tuberculoma is largely presumptive in the absence of its nonspecific appearance.

The accurate diagnosis of tuberculoma is not possible until the brain lesion in question is subjected to histopathological examination as a similar picture can be produced by neoplasms, other granulomatous diseases or viral, fungal and bacterial infections obstructing the foramen of Monro on one side. Serological evidence of tuberculosis may prove useful in the absence of histopathological confirmation. Gene amplification by the polymerase chain reaction (PCR) to identify mycobacterial DNA has been used with great sensitivity and specificity and offers great promise for rapid diagnosis if available (1).

Intracranial tuberculoma has been described at various locations in both the supratentorial and infratentorial compartments. Clinically, it is seen in adults and is characterized by a lengthy course. The clinical features depend on location and include headache, vomiting, blurring of vision, focal seizures, weakness of limbs and neck tilt. The tuberculoma in this case report obstructed the foramen of Monro on one side, resulting in unilateral hydrocephalus.

Oi et al. (12) classified unilateral hydrocephalus into four categories. According to this categorization, category 1 is congenital atresia of the foramen of Monro. Category 2 is morphological obstruction of the foramen of Monro. Functional obstruction of the foramen is category 3, whereas hydrocephalus due to unbalanced intracranial compliance or unilateral parenchymal change falls into category 4 . The clinical significance of this classification is questionable and adds nothing to management.

Although ventriculo-peritoneal shunt is a simple method for immediate relief of symptoms associated with hydrocephalus, the complications related to VP shunts are many with a reported incidence of $24-47 \%$, of which abdominal complications are reported to occur in $25 \%$ (5). Other rare complications include migration of the peritoneal catheter, spontaneous umbilical CSF fistula, overdrainage, and cervical myelopathy $(2,11)$. Endoscopic fenestration of the occluded foramen of Monro or septum pellucidum is an encouraging method of establishing a CSF pathway.

Endoscopic septostomy is safe, less invasive and results in few complications. Intraoperative navigation and a biportal approach are helpful in establishing the intraoperative orientation in difficult cases (8).

When a diagnosis of tuberculoma is considered, a trial of antituberculous therapy should be instituted even without histopathological confirmation. However, the response to chemotherapy varies as these lesions are known to increase in size on treatment, adding to problem of management (14). Mayer et al. (10) suggested triple drug therapy for the first 3 months. The use of steroids is controversial (10). The optimal duration of treatment is uncertain, although treatment for more than 1 year is advocated by most clinicians (9).

Individualizing the treatment is the key to successful management of intracranial tuberculomas, as in our case where the raised intracranial pressure was successfully treated by endoscopic septostomy followed by antituberculosis drugs to stamp out the disease.

\section{CONCLUSION}

An intracranial tuberculoma is a potentially curable disease that must be differentiated from other intracranial spaceoccupying lesions. Early diagnosis and prompt therapy with antituberculous drugs are important in preventing mortality and reducing morbidity. Hydrocephalus due to meningitis or tuberculoma obstructing the CSF pathway can be effectively treated with neuroendoscopic third ventriculostomy or septostomy wherever indicated. Intraoperative navigation and a biportal approach are helpful in establishing orientation in difficult cases with multiple septa formation 
and wide asymmetricity of the ventricles. Antituberculous chemotherapy results in an improvement in almost all and a cure in most cases.

\section{REFERENCES}

1. Ahuja GK, Mohan KK, Prasad K, Behari M: Diagnostic criteria for tuberculous meningitis and their validation. Tubercle \& Lung Dis 75:149, 1994

2. Borkar SA, Satyarthe GD, Khan RN, Sharma BS, Mahapatra AK: Spontaneous extrusion of migrated ventriculoperitoneal shunt catheter through chest wall: A case report. Turk Neurosurg 18: 95-98, 2008

3. Braun WM, Cote TR, Rabkin CS: Trends in death with tuberculosis during the AIDS era. JAMA 269(22):2865-2875, 1993

4. Desai BB, Shah VC, Tavri OJ, Rao P: MRI: More specific than CT in cranial tuberculomas. Neuroradiology 33:216, 1991

5. Ghritlaharey RK, Budhwani KS, Srivastava DK, et al: Trans-anal protrusion of ventriculo-peritoneal shunt catheter with silent bowel perforation: Report of ten cases in children. Pediatr Surg Int 23:575, 2007

6. Gree GT, Bazan III C, Jinkings JR: Miliary tuberculosis involving the brain. MR findings. AJR 159:1075, 1992

7. Gupta RK, Jena A, Sharma A et al: MR imaging of intracranial tuberculoma. J Compt Assist Tomogr 12:280, 1988
8. Hamada H, Hayashi N, Kurimoto $M$, Umemura $K$, Hirashima $Y$, Endo S: Neuroendoscopic septostomy for isolated lateral ventricle. Neurol Med Chir (Tokyo) 43:582-588, 2003

9. Lepper $\mathrm{MH}$, Spies HW: The present status of the treatment of tuberculosis of the central nervous system. Ann NY Acad Sci 106: 106-123, 1963

10. Mayers MM, Kaufmann DD, Miller MH: Recent cases of intracranial tuberculomas. Neurology 28:256-260, 1987

11. Mohindra S, Singla N, Gupta R, Gupta SK: CSF fistula through the umbilicus following a shunt surgery: A case report and literature review. Pediatr Neurosurg 43:396-398, 2007

12. Oi S, Matsumoto S: Pathophysiology of nonneoplastic obstruction of the foramen of Monro and progressive unilateral hydrocephalus. Neurosurgery 17:891-896, 1985

13. Ramamurthi B, Varadarajan MG: Diagnosis of tuberculomas of the brain: Clinical and radiological correlation. J Neurosurg 18:1, 1961

14. Teoh R, Hymphries MJ, O'Mahony G: Symptomatic intracranial tuberculoma developing during treatment of tuberculosis: A report of 10 patients and review of literature. Q JMed 63:449, 1987 